\title{
World Association for Psychosocial Rehabilitation
}

The World Association for Psychosocial Rehabilitation is looking forward to its next International Congress hosted by its Irish Branch in Dublin from September 26-29, 1993. At our last Congress October, 1991 in Montreal 1,100 participants gathered from 50 nations around the globe to share ideas, meet with colleagues and present new scientific findings. At the Dublin Congress next year we anticipate that 1,500 delegates will attend, with a sizeable number of our 70 National Secretaries from countries around the world being amongst those attending.

We expect many of the key leaders in our field to speak and to share with us their ideas and plans for the future. Immediately preceding the Congress we will host workshops for professionals who wish to improve their technical expertise and obtain additional training in various aspects of psychosocial rehabilitation. The Congress will feature plenary sessions, with a chance to hear internationally well known leaders in our field, scientific presentations, research and concept papers on a wide range of topics.

Concurrent with the Congress, a call has been issued for a meeting of the leaders of associations of families of the mentally ill. It is hoped that this meeting will result in the formation of a much needed World Association of the Families of the Mentally Ill. Consumer issues will be addressed and it is our intention that consumers of psychiatric services will actively participate in the programme.

It may be of interest to the readers of the Irish Journal of Psychological Medicine to learn some of the history of our Association.

Our first international meeting was held in Helsinki in 1971. Among the key figures who helped bring the meeting to fruition and delineate our concepts were (from the US) Nathan S Kline, Irving Blumberg, James Garrett, Ernest Gruenberg; (Ireland) C. McDonnell; (UK) Douglas Bennett, Donal Early; (Estonia) J. Saarma; (France) Pierre Bailly-Salin, Roger Amiel; (Colombia) Carlos Leon; (Finland) T. Pikhanen and (Nigeria) Tolani Asuni. The meeting ended with a call for an international association.

Like many calls for action, our call for an international association was met with an expectant silence on the part of the mental health community. From then on the work was simple . . those of us who saw the need would also have to do the work. In the years that followed, we learned to "piggyback" at other congresses, holding satellite meetings at the same time as conferences were being held by the World Psychiatric Association, Rehabilitation International, the World Association for Social Psychiatry and also at meetings held in Geneva by the World Health Organisation and the International Labour Organisation.

By these means and with a newsletter edited by Irving Blumberg and by holding occasional Advanced Institutes we were able to gradually build a network of about one thousand correspondents and specialists around the world. With this group as our nucleus and with the mighty and indispensable help of our French colleagues, we were finally able to host an official Congress of our own in Lyon and Vienne, France in 1986. Since then our bi-annual Congresses have grown by leaps and bounds.

Dublin will be our fourth World Congress and we look forward to meeting the readers of the Irish Journal of Psychological Medicine in Trinity College, Dublin from September 26-29, 1993. We hope that you will not only attend our Congress and become a member of the Association but that you will become involved in our work through our committees and by our consultants who collaborate with agencies of the United Nations, such as the World Health Organisation.

We believe that it is important to help and advocate for the mentally ill, not only in our respective countries and at annual meetings, but also during the time between meetings and in other countries. Much of our energy is devoted towards helping the mentally ill in developing countries. We have continued to collaborate with local professionals and the World Health Organisation to put in place low cost basic mental health systems and community based rehabilitation programs which train the families of the mentally ill in several countries in Africa, Asia and Latin America. Right now we are looking to recruit someone who can set up a mental health system in Angola, a country that has been devastated by war and presently has no mental health care whatsoever.

Whether your interests in the field of psychosocial rehabilitation are academic, research, clinical or from a human rights perspective, we want to meet you in Dublin.

\section{Martin Gittelman,}

President, World Association for Psychosocial Rehabilitation, New York Medical College, Lincoln Hospital, 234 East 149th Street, New York, NY 10451.

Editor in Chief: Mark Hartman (Dublin). Editors: Timothy Dinan (London), Roy McClelland (Belfast). Deputy Editor: Brian O'Shea (Dublin). Associate Editors: Ken Brown (Belfast), Patricia Casey (Dublin), Anthony Clare (Dublin), Stephen Cooper (Belfast), Thomas Fahy (Galway), Michael Fitzgerald (Dublin), Michael Kelleher (Cork), David King (Belfast), Brian Leonard (Galway), Aidan McGennis (Dublin), Ciaran O'Boyle (Dublin), Eadbhard O'Callaghan (Dublin), Art O'Connor (Dublin), Ethna O'Gorman (Belfast), lan Pullen (Edinburgh), David Sheehan (Tampa), Philip Snaith (Leeds), Hugh Staunton (Dublin), John Waddington (Dublin), Richard Williams (Calgary). Statistical Editor: Leslie Daly (Dublin). Deputy Statistical Editor: Ronan Conroy (Dublin). 